\title{
Køn i cyberspace
}

Af Randi Markussen

Hpad er cyberspace? Hoad bar kon med cyberspace at gore? Hvordan kan kon $i$ cyberspace tematiseres? Cyborg feminisme ses som anvendeligt til at gentonke forboldet mellem det teknologiske og det sociale. Hvad kan saidan en synsswinkel sige om køn i cyberspace?

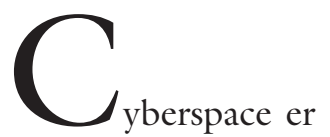

et af de begreber, som er ved at vinde indpas i det danske sprog, trt forbundet med andre spektakulære udtryk som internet og WWW, multimedier, informations motorveje eller infrastrukturer, virtual reality you name it. Disse fænomener samles ofte under en anden neologisme, betegnelsen IT, informationsteknologi, en praktisk forkortelse for disse nyudviklinger, som forbinder det spektakulære med det mere prosaiske og velkendte ved at inkludere begreber som for eksempel computerisering, kybernetisk teknologi, kunstig intelligens, automatisering, computer-medieret kommunikation. Som tendens omfatter de også velkendte medier som telefon, fjernsyn og radio, efterhånden som de digitaliseres $\mathrm{og}$ bringes på samme 'teknologiske formel.'

Det er en imponerende udvikling, som inkluderer en globaliserende og internationaliserende tendens, teknisk, økonomisk og kulturelt, og som aktualiserer forholdet mellem det lokale og det globale og masse- 
mediers betydning og funktion. Den udfordrer samtidig grundlæggende arbejdsdelinger i vores kultur mellem på den ene side det, vi traditionelt opfatter som teknisk og som har med forholdet til naturen at gøre, og det, der på den anden side handler om den sociale og kommunikative verden, kort sagt dybt naturaliserede opfattelser af forhold mellem materialitet og betydning.

Det berører således veletablerede teoretiske problemstillinger inden for den feministiske debat om kønsforskelle og hvilket stof, de er gjort af, om forholdet mellem køn, kultur og natur, ofte tematiseret omkring distinktionen mellem sex /gender biologisk og kulturelt køn. Ikke mindst kontroverserne i denne debat har bidraget til, at den feministiske diskussion udgør et inspirerende felt for diskussioner af de dynamiske processer, der er på spil i menneskers arbejde med at tolke og tilegne sig verden, idet køn må siges at udgøre en af de mest fundamentale og naturaliserede måder at klassificere og skabe orden i verden på. Det finder sted på det elementære samfundsmæssige plan, idet vi for eksempel kategoriseres efter køn med navn og vores personnummer ved fødslen og herefter i enhver bureaukratisk sammenhæng. Og det sker alle steder mennesker mødes, idet vi som regel bliver usikre på situationen, hvis vi ikke umiddelbart kan placere mennesker efter det ene eller det andet køn.

Uanset hvordan forskellige feministiske strømninger tolker køn, udgør stereotype repræsentationer, hvor mænd forbindes med det tekniske og kvinder med det sociale et virksomt filter både konkret og symbolsk i den kulturelle virksomhed i vores samfund, uanset mænds og kvinders faktiske færden. Men i processer, hvor vante kulturelle grænsedragninger er i opløsning, er der en mulighed for at tydeliggøre og problematisere dominerende forestillinger om teknologi, køn og samfund og bringe andre forståelser i spil.

Hvad er cyberspace? Hvad har køn med cyberspace at gøre? Hvordan kan køn i cy- berspace tematiseres? Valget af cyberspace som begreb og indfaldsvinkel til den informations-teknologiske udvikling, og for eksempel ikke arbejdet i de utallige standardiserings-komiteer, som udgør et vigtigt element i IT- udvikling, opfordrer til at undersøge det spektakulære omkring nye teknologier og hvordan det fremkommer, samt se på hvordan det forholder sig til feltet i en mere omfattende forstand.

I det følgende vil jeg tage læseren med på en rejse rundt omkring nogle af de på én gang metaforiske, politiske, tekniske og kommunikative steder, som informationsteknologi formes i. Op imod den dominerende forestilling om teknologi som en verden for sig, som adlyder sine egne love og adskiller sig radikalt fra den sociale og menneskelige verden, hvor vi til gengxld kan udnytte teknologien eller gøre vores bedste for at beskytte os imod den, sætter jeg et billede af teknologi som et heterogent netværk, en række uadskillelige sociotekniske og diskursive mødesteder. De kan anskues som 'rum' eller laboratorier, der på den ene side er forbundet og i konstant interaktion med verden omkring, men som på den anden side også afgrænses af bestemte, omend skiftende dynamiske diskursive og magtmæssige konstellationer. Bliver vi i billedet af space vil denne synsvinkel fremhæve, at vi på en ene side har at gøre med noget, der er blevet gjort globalt, space i betydningen det vidtstrakte rum, men på den anden side også, at det globale samtidigt er lokalt hele vejen igennem, space i betydningen mellemrum.

Formålet med rejsen er at formidle et indtryk af den informationsteknologiske udviklingsdynamik, som kan stimulere til en bred diskussion af $\mathrm{k} ø \mathrm{n}$ og informationsteknologi. Jeg vil begynde med en global og allestedsnærværende aktivitet, som jeg har kaldt det metaforiske arbejde, et værksted, som smeder både køn og teknologi. Det vil jeg bruge som udgangspunkt for at se nærmere på metaforen cyberspace og sætte den ind i en historisk sammenhæng. 


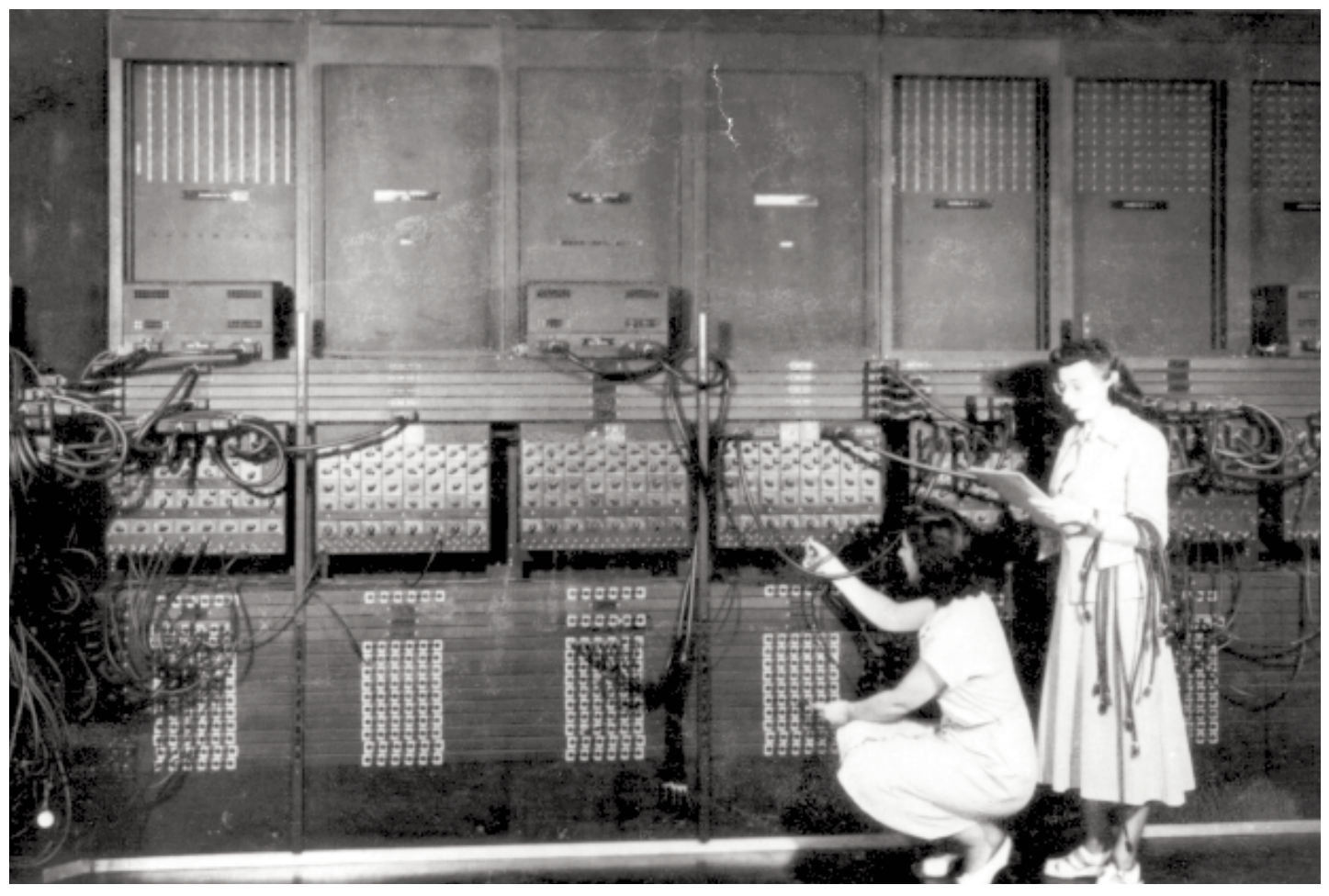

U.S. Army photo of two women wiring the ENIAC with a new program. Kilde: Mike Muns s Historic Computer Images site. 
Desuden vil jeg analysere metaforen cyborg, som den amerikanske biolog og videnskabsteoretiker Donna Haraway har introduceret. Cyborg er ment som en inspirationskilde til at begribe eksistensvilkårerne $\mathrm{i}$ en verden, der er gennemsyret af moderne teknovidenskaber og til at udvikle alternative forståelser heraf. Som sådan har den også stimuleret til ideen om det metaforiske arbejde og forståelsen af teknologi som et netværk af sociotekniske og diskursive mødesteder, som jeg benytter mig af i denne fremstilling. Turen slutter med et hastigt blik på diskussionen af IT og informationssamfundet i Danmark, med henblik på at skitsere, hvordan en 'fornemmelse for $\mathrm{cy}^{-}$ borg' afkoder den dominerende diskurs om informationssamfundet.

\section{DET METAFORISKE ARBEJDE}

Metaforers betydning for vores tilegnelse af verden har været genstand for en del opmærksomhed i kognitionsforskning og filosofi i de senere år (Olesen,1992). Både køn og teknologi er interessante områder at afprøve de erkendelsesmæssige muligheder i sådanne perspektiver. I det følgende vil jeg tage udgangspunkt i filosoffen Max Blacks klassiske artikel om metaforer (Black,1955).

Black skelner mellem på den ene side en substitutions- og sammenligningsforståelse og på den anden side en interaktionsforståelse af metaforen. Den forste er den mest udbredte og beror på den forestilling, at metaforen kan erstattes af et bogstaveligt udtryk. 'Richard er en løve' eller for at nævne et andet eksempel, Anja er en løvinde, kan ud fra en substitutionsforståelse erstattes med at Anja/Richard er modige (Black,1955:71). Sammenligningsforståelsen er mere sofistikereret, idet den implicerer, at udsagnet handler om både Anja/Richard og løver, nemlig at de er modige. Jeg vil komme ind på interaktionsforståelsen om et øjeblik, men først lige fremhæve, at et af de fænomener, Black nævner under substitutonsforståelsen, spiller en stor rolle i teknologisk udvikling. Frembringelsen af noget nyt involverer spørgsmålet om at navngive og begrebsliggøre fænomenet for overhovedet at kunne håndtere det $\mathrm{og}$ kommunikere om det. Begreber som computer, elektronhjerne, programmeringssprog, datamat, informatik, pc'er, internet, protokol, cyberspace, main-frame, harddisk, software, bærbar osv. er alle udtryk for en art af fænomenet katakrese, nemlig der hvor vi bruger metaforer til at 'lukke huller i sproget' (1955:69). Er det en vellykket proces, hvor det metaforiske fænomen naturaliseres og bliver en selvfølgelig del af hverdagen for dem, der er i kontakt med det, ender vi samtidig med døde metaforer, som det så sigende hedder, når fænomenet ender med at leve, og vi ikke længere tænker over den betydning, ordet havde eller har i andre sammenhænge.

Skal vi tage det metaforiske arbejde på ordet, kræver det imidlertid i følge Max Black, at vi graver dybere i de mekanismer, der er på spil. Det virkelig interessante ved metaforer er, at der etableres en interaktion mellem to forskellige områder, hvor meningen er et resultat af interaktionen (1955:72). Black taler om en interaktion mellem et primært subjekt og et sekundært subjekt og det 'system af almindeligheder,' som knytter sig til det sekundære subjekt. Metaforen fungerer, hvis det system af almindeligheder, der bringes i spil, virker meningsfuldt og attraktivt i den givne sammenhæng, uanset om almindelighederne er korrekte i forhold til de gældende videnskabelige eller andre sandheder på området. Pointen ved denne interaktionsforståelse til forskel fra sammenligningsforståelsen er, at der skabes en ny mening, som vil farve både vores opfattelse af det primære og det sekundære subjekt, hvis metaforen slår an.

Tag et udtryk som intelligent legetøj, som jeg hørte i TV-avisen for nylig, som betegnelse for det computerstyrede legetøj, MIT (Massachusets Institute of Technology) i USA, et af de førende teknologiforsk- 
ningscentre i verden, og det danske firma Lego er ved at udvikle. Legetøj er i dette udsagn det primære subjekt og intelligens det sekundære. Indslaget var da også struktureret som en udforskning af disse begrebers interaktion og de interessante indsigter, det kunne give anledning til. Det system af almindeligheder, som blev knyttet til intelligens var i denne TV-avis, at det er udtryk for at kunne beherske noget vanskeligt og at især beherskelsen af IT kræver og udvikler intelligensen, jævnfør også den klassiske betegnelse AI (Artifical Intelligence), kunstig intelligens, om nogle IT systemer. I interaktionen mellem intelligens og legetøj skabes forventningen, at selv børn ville kunne bringes til at bruge det og dermed måske udvikle deres egen intelligens. En pointe i interaktionsforståelsen er imidlertid, at hvis metaforen slår an, og der i dette tilfælde udvikler sig en praksis, hvor børn i almindelighed leger med det intelligente legetøj, så vil vi enten holde op med at kalde det intelligent, eller vi vil redefinere begrebet om intelligens. Andre systemer af almindeligheder, som giver mening i forhold til den praksis, der er tale om, vil bringes i spil, for eksempel at intelligens er et dagligdags og udbredt fænomen. Det springende punkt vil selvfølgelig være, om vi uden videre vil inkludere teknologien som intelligent på linje med mennesker.

\section{KøN OG DET METAFORISKE ARBEJDE}

Metaforer organiserer vores forståelse på en dynamisk facon, som skaber ny mening til både det primære og det sekundære subjekt. Forståelse er desuden en integreret del af at handle i praksis. Systemer af almindeligheder er ikke til at spøge med, netop fordi de ikke er entydige, men virker i kraft af flertydigheden. Tænk blot på de systemer af almindeligheder, som handler om køn. Opfatter vi køn som en metafor, der organiserer og medierer vores relationer til andre, er det interessant, at 'systemer af almindeligheder' ikke alene er flertydige, men også at der er forskellige systemer af almindeligheder, forskellige teoridannelser om køn og kønnets betydning, i spil. Kvindeforskning og megen kultur- og naturvidenskab, litteratur og medier og hverdagslivet med, handler jo i dag i høj grad om at udfordre og udfolde disse spillerum og gøre forskellige systemer af almindeligheder virksomme. Teorier om køn er også historiske og dermed foranderlige. Når feminismen er så dynamisk et felt i dag skal det derfor ses $\mathrm{i}$ forbindelse med, at køn og kønsrelationer også uden for den teoretiske verden er i forandring.

Et eksempel på dette kan være den episode, videnskabsteoretikeren og biofysikeren Evelyn Fox Keller beskriver i bogen Reflections on Gender and Science (1985). Efter hun er begyndt at beskæftige sig med køn og videnskab, møder hun en af sine tidligere professorer, som interesseret spørger hende, hvad hendes studier så har vist om kvinder. Han viser hermed, at han forstår køn inden for det meget udbredte 'system af almindeligheder,' hvor kvinde er markeringen af kønslig forskel, og hvor relationen mellem kønnene konstrueres som et system af hierarkiske oppositioner. Videnskab og mænd repræsenterer en universel 'menneskelig' erkendelsesinteresse, kvinder en partikulær og dermed mindreværdig. Han ser kvinder som problemet, uafhængigt af de definerende magtrelationer, som konstituerer kategorien kvinde. Evelyn Fox Keller er derimod interesseret $\mathrm{i}$ relationerne og $\mathrm{i}$ at fremanalysere konsekvenserne af en forståelse som hans, og ikke mindst, hvad det har betydet for videnskaben, at den har været så mandsdomineret. Der udspringer som bekendt meget forskellige handlingsstrategier af de to synspunkter.

Evelyn Fox Kellers egen situation kan imidlertid give anledning til at etablere en anden kønsmetafor med et andet system af almindeligheder. Professoren opfatter jo ikke hende som en del af den problematiske kategori, kvinde, den har hun tilsyneladende hævet sig op over ved at blive en berømt 
og anerkendt biofysiker. Hun er altså i en situation, hvor hun på én gang både er og ikke er kvinde, og heller ikke en mand. Forskellen destabiliseres; det er vanskeligt at opretholde en forståelse af en absolut og homogen forskel, hvor individer entydigt går op i enten den ene eller den anden kategori. Hvad er det at være kvinde, hvis hun på samme tid både kan repræsentere det og ikke? Forskellen viser sig i stedet som en dynamisk forskelsætten og dermed som et historisk og foranderligt fænomen. Det er denne opfattelse af køn og dermed et nyt system af almindeligheder, som Donna Haraway vil fremmane med cyborg metaforen, som jeg vil komme tilbage til.

\section{SKITSE TIL INFORMATIONS-}

\section{TEKNOLOGIENS GENEALOGI}

Når det drejer sig om den teknologi, som cyberspace refererer til, forekommer det mig, at det metaforiske arbejde indfanger de mekanismer, der er på færde i teknologisk udvikling på en lige så interessant facon som med køn. En side af sagen er det forhold, som handler om at 'lukke huller i sproget.' En anden er de systemer af almindeligheder, som aktualiseres omkring de anvendelser og de praksisser, som bevirker, at betegnelser bliver til døde metaforer. Begrebet computer, regnemaskine, henviste for eksempel til, at artefaktet blev anvendt til beregninger. Den nye maskine blev betragtet som primært subjekt i en interaktion med det sekundære subjekt, at beregne. Efterhånden som computeren blev udbredt, udkrystalliserede der sig en ny betydning af, hvad det vil sige at beregne. Men hvilke dele dækker dette navn over i den pc'er, læseren formodentlig er bekendt med? Skærmen var for eksempel ikke en del af den maskine, men kom til senere. Elektronhjerne var også en tidlig metafor, som sjældent bruges i dag, omend de pc'ere, vi i dag anvender, har en langt større kapacitet. Men hjernemetaforikken spiller stadig en rolle, som eksemplet med det intelligente legetøj viser. Hjernemetaforen er et godt eksempel på den interaktionsdynamik, som Black beskriver. På den ene side forstås edb-maskinen i hjernens billede, den er det primære subjekt, som forbindes med det system af almindeligheder, der i vores kultur knytter sig til det sekundære subjekt, hjernen, nemlig det at tænke og ikke mindst den status, som er forbundet hermed i vores samfund. På den anden side bliver den videnskabelige opfattelse af hjernen præget af det primære subjekt og udforskes ud fra de egenskaber, som computeren udviser i praksis.

Selvom hjernemetaforer ikke er de mest benyttede i designarbejde og systemudvikling $\mathrm{i}$ dag, har de sat deres præg på den almindelige opfattelse af, hvad computerteknologi er, som er med til at forlene den med magt og status. Skift i metaforer kan selvfølgelig skyldes mange ting. Et af mine yndlingseksempler er Lucy Suchmans etnometodologisk inspirerede analyse af brugen af et system, der er udviklet ud fra en AI (kunstig intelligens) tankegang, og som viser, at brugerne ikke tænker og handler, sådan som systemet forventer. Systemet skulle instruere i brugen af en kopimaskine, men i praksis viser det sig, at brugerne ikke tænker ud fra den kartesiske kognitionsforståelse, som systemet repræsenterer. Det er et eksempel på, at nogle metaforer kan have svært ved at slå an og forbinde sig med en menneskelig praksis (Suchman,1987).

Nye metaforer kan ses som forsøg på at aftvinge designarbejdet ny viden. Det metaforiske arbejde gør sig lige såvel gældende, når vi taler om computeren som et værktøj eller som et medium eller som et sammenhængende logisk system. Hver for sig lægger de forskellige opfattelser op til handlingsstrategier, der fremhæver bestemte træk ved den situation, der designes i, og overser andre. Det afgørende spørgsmål ud fra min cyborginspirerede tilgang er således ikke, hvilken beskrivelse af denne maskine, som er den sande. Spørgmålet er i stedet, hvordan forskellige metaforer organiserer 
og har organiseret både maskinen og vores indsigter og handlinger omkring den og dens videre anvendelsesmuligheder. Maskinen opfattes som et grundlæggende historisk fænomen. En beskrivelse af den teknologiske udvikling kunne således tage form af en genealogisk fremstilling af, hvilke metaforer, der har været dominerende i bestemte historiske sammenhænge og knyttet til bestemte mere eller mindre omfattende arbejdsområder og miljøer. Cyberspace er et eksempel på en relativ ny metafor og indfaldsvinkel til at forstå teknologien. Hvilke systemer af almindeligheder forbindes den med, hvor kommer den fra og $\mathrm{i}$ hvilke sammenhænge anvendes den?

\section{Cyberspace}

Begrebet har litterære aner, idet det tilskrives William Gibson i science fiction romanen Neuromancer fra 1984. Det er her betegnelsen for en fantasi om et verdensomspændende computerstyret netværk, hvor interaktionen er baseret på sofistikerede virtual reality teknologier i en dystopisk verden, som er domineret af multinationale selskaber og hvor samfundet er gået i opløsning. Cyberspace benævnes også matrix'en, et ord, der som bekendt stammer fra det latinske mater. Det er værd at citere Gibsons egne overvejelser over metaforen, i det $\varnothing$ jeblik den bevæger sig fra hans litterære verden og ind i en akademisk orienteret systemudviklingsverden. Det er i antologien Cyberspace: First Steps (Benedikt,1991):

"Assembled word cyberspace from small and readily available components of language. Neologic spasm: the primal act of pop poetics. Preceded any concept whatever. Slick and hollow - awaiting received meaning.

All I did: folded words as taught. Now other words accrete in the interstices.

"Gentlemen, that is not now nor will it ever be my concern...."
Not what I do.

I work the angle of transit. Vectors of neon plaza, licensed consumers, acts primal and undreamed of..." (Gibson,1991:27).

Gibson opfatter ikke sig selv som fremtidsforsker og lægger afstand til den transformation af metaforen, som finder sted i det nye mødested. Den mening, metaforen fyldes med i designersammenhængen, tager afsked med den melankolske, dystopiske og tvetydige teknofantastiske tone, som præger Gibsons univers. Den erstattes som regel af en anderledes uskyldig og begejstret trang til at udvikle og designe computernetværk, nye netbaserede interaktionsog kommunikationsmuligheder og forestillinger om at frigøre sig fra de tids- og rumlige bindinger, som er strukturerende i de samfundsmæssige organiseringer, vi er vant til. Cyberspace er et "unhappy word," som redaktøren Michael Benedikt skriver $\mathrm{i}$ introduktionens første linjer, hvis vi - med mine ord - fastholder det 'system af almindeligheder,' som knytter sig til Gibsons brug af begrebet. Cyberspace skal i stedet være navnet for "a new stage, a new and irresistible development in the elaboration of human culture and business under the sign of technology." (Benedict,1991:1)

Med sin blanding af fiktion, filosofiske reflektioner, konkrete designforslag, overvejelser over nye muligheder for kommunikation i mediet, analyser af flerbrugerspil til nettet og fiktionsprægede historier om teknologiens udvikling demonstrerer denne antologi og mange andre i samme stil, at det metaforiske arbejde i design lader sig inspirere af fiktion. Men også at betydninger af metaforen transformeres, det øjeblik den transporteres ind i en ny sammenhæng et nyt mødested. Idet metaforer vandrer fra det ene mødested til det andet, tillægges de forskellige betydninger, alt efter hvordan nye kontekster fortolkes af de involverede og sætter sig igennem som forståelser af et nyt fænomen. De let tilgængelige komponenter, som Gibson sammenstykkede be- 


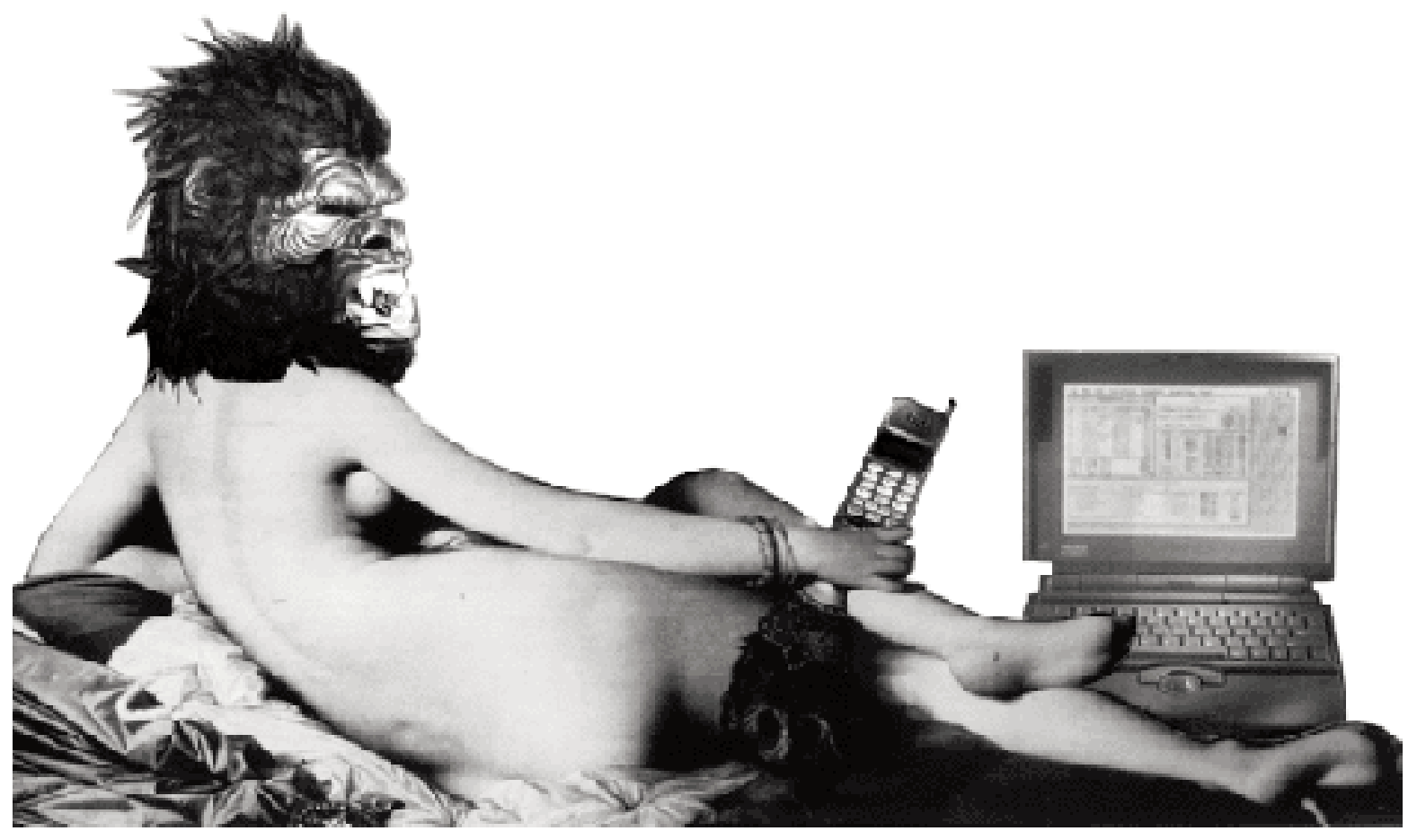


grebet af, stammer blandt andet fra den videnskabelige verden, hvad betegnelsen science fiction også indikerer. Cyber henviser til kybernetik, et ord som matematikeren Norbert Wiener tog fra det græske ord for styrmand, kubernetes (Wiener, 1963: 14). Han brugte det til at betegne en universel teori om kommunikation og kontrol i og imellem levende organismer, samfund såvel som maskiner, hvor begrebet om feed back og dermed selvregulering og læring spiller en afgørende rolle. Teorien udsprang desuden af arbejdet med at udvikle styringssystemer til luftværnssystemer under anden verdenskrig, og fungerede således som metafor for en tidlig udvikling af 'elektronhjernen,' men på en måde, hvor hjernen stadig var legemliggjort og ikke udspaltet på kartesisk vis, som i de senere AI systemer. (Edwards, 1996: 240). Kybernetiske systemer anvendes da også som en tidlig betegnelse for computeriserede kontrolsystemer (Hirschhorn, 1984). Cyber-betegnelsen har således et 'system af almindeligheder' knyttet til sig, som inspirerer både Gibson og designere til at tænke i kropsliggjorte interaktions-muligheder og 'sammensmeltninger' af menneske-maskine, og ikke alene en skriftbaseret visuel interaktion. Cyberspace betegner i denne forstand et styret rum, forankret i og muliggjort af et stort register af kropsliggjorte interaktionsformer.

\section{CYBERSPACE SOM METAFOR FOR INTERNETTET?}

Det er mit indtryk, at cyberspace i dag af mange anvendes som en metafor for internettet/WWW, men med en fokusering på de mere spektakulære former for selvudfoldelse omkring spil, leg og kommunikation, som nettet muliggør i form af mødesteder og interaktionsmuligheder. Udgangspunktet er den enkelte som individ og privatperson, der kan udforske sin identitet og ikke mindst kønsidentitet ved at agere som en fremmed blandt fremmede med de mulig- heder for åbenhed, som et sådant møde rummer (Schutz, 1977). Køn i cyberspace vil uden tvivl også få mange til at associere til, at pornografi er big business på nettet; det erindrer om, at nettet ikke alene er en del af den omgivende verden, men også at langt de fleste brugere i cyber verdenen stadig er mænd. Cyberspace giver en mulighed for påny at orkestrere 'klassiske' figurer i det anonyme moderne storbyliv som flanøren, dandy'en, og giver mulighed for mange former for (windows)shopping og osen omkring, men nu i en ganske anden skala og dermed organisering af oplevelsen. Windows markerer således en dobbelthed, idet 'at kigge på vinduer' på nettet foregår gennem et vindue, hvis vi tager metaforen fra et af de mest udbredte systemer, Windows, på ordet. Gadebilledet er da også en brugt metafor i multimedie-organiseringen af adgangen til internettet/WWW, som henvender sig til privatpersoner, som for eksempel TeleDanmarks system Opacia.

Hvis det 'system af almindeligheder,' som er ved at udkrystallisere sig omkring metaforen cyberspace har privatpersonen og subjektiviteten som tema og omdrejningspunkt, er det værd at erindre, at metaforen stammer fra et tidspunkt, hvor pc'eren netop begyndte at komme frem, nemlig i slutningen af 70'erne. Den personlige computer har været en virksom metafor, idet valget af 'personlig' rammer et centralt princip i organiseringen af selvforståelsen i vores kultur. Den har haft en helt anden appel end den elitære AI metafor. Den er endvidere et eksempel på, hvordan det sekundære subjekts kvaliteter kommer til at farve vores opfattelse af det første subjekt, når metaforen lykkes. I debatten om IT i offentligheden i dag ligger der ofte den uudtalte præmis, at for at blive en person, der udvikler sig og lærer, idet hjernemetaforen ofte 'svinger med' i forståelsen af computeren, så må man have helt sin egen maskine. Tankegangen synes at være, at samfundet vil blive endnu mere demokratisk, jo mere det består af oplyste, vidende 
mennesker, som ved hjælp af IT har frigjort sig fra kendte sociale og materielle bindinger. Det er et tema i Infosamfundsrapporten (Dybkjær \& Christensen, 1994). I debatten om IT i skolesystemet går man som regel ud fra som en selvfølge, at hver elev skal bære rundt på sin egen computer uden at diskutere andre organiseringer af teknologien. At den højt besungne frigørelse er ensbetydende med en ny afhængighed af IT er en side af medaljen, som sjældent nævnes i denne retorik.

Holder vi fast i begge sider af medaljen kan både retorikken og de praksisser, der udvikler sig omkring nettet, anskues som led i omfattende restruktureringer af hvad vi med Foucaults udtryk kan kalde disciplinære teknikker (Foucault, 1977). Hvor retorikken fremhæver nye muligheder for individuel selvudfoldelse og opløsning af hierarkiske organisationsformer og snærende samfundsmæssige bånd, vil denne tilgang samtidig pege på, at bureaukratiet ikke er på retur, men under transformation. De tids- og rumlige omstruktureringer af hverdagslivet, som IT udvikles som et led i, kan ændre på vante grænser mellem steder for arbejde, samvær, leg og hjemmeliv, men stiller samtidig store krav til disciplinering, koordinering og planlægning. Den efterhånden allestedsnærværende skrivebordsmetafor med mapper og papirkurv kan måske pege på, at sider af bureaukratiet, netop betegnelsen for et skrivebord, omvendt trænger sig på som strukturerende princip i langt flere arbejds- og livssammenhænge. Udvikling af informations infrastrukturer beror i stor udstrækning på omfattende standardiseringer af mange vidensfelter, som for eksempel i tilfældet af den elektroniske patientjournal og lignende systemer (Bowker \& Star,1996). Angivelsen af køn i CPR-registreret er ikke blot en uskyldig og neutral markering af en naturgiven forskel, men en aktiv metafor for individets videre vej og færden. 'Leg' med identiteter udfolder sig ligefuldt i bureaukratiske informationssystemer.
Vil cyberspace stabilisere sig som en metafor for internettet/WWW, og hvilke 'systemer af almindeligheder' vil i givet fald blive knyttet til den? Vil det blive den snævre betydning med fokus på individet, men også på destabiliseringen af denne kategori i 'legen' på internettet, eller vil den også rumme en forståelse af mere omfattende (destabiliserende) konstruktioner af subjektivitet i de komplekse sociotekniske og diskursive mødesteder, som internettet/WWW og dets udvikling indgår i? For hvem vil cyberspace være en foretrukken metafor og i hvilke sociale sammenhænge vil den primært slå an?

Det er selvfølgelig umuligt at svare på, ligesom det på nuværende tidspunkt er svært at vide, om alle hjem i Danmark, $\mathrm{m} / \mathrm{k}$, vil investere $\mathrm{i}$ at koble sig op på nettet. Virker metaforen idag primært der, hvor internettet/WWW stadig kan opfattes som nyt og spektakulært, netop fordi det ikke er forankret i en dagligdags praksis? Cyber-betegnelsen har i al fald haft appel i meget forskellige former for akademiske og litterære sammenhænge som et begreb, der antyder komplekse 'sammenfiltringer' af teknisk-videnskabelige og sociale relationer. Et begreb, hvor en ontologisk skelnen mellem forholdet til naturen og det sociale udviskes, omend på markant forskellige måder. Det gxlder også et af de feministisk set mest interessante forsøg på bevidst at udnytte magten i det metaforiske arbejde til at inkarnere nye forståelser af, hvad det vil sige at være (kvinde)menneske idag, nemlig Donna Haraways begreb om cyborg. ${ }^{1}$

\section{CYBORG SOM IKON FOR}

\section{FEMINISTISK POLITIK}

Donna Haraways essay 'A Cyborg Manifesto: Science, Technology, and Socialist-Feminism in the Late Twentieth Century' udkom på omtrent samme tid som Neuromancer, og hendes tour de force i fremmaningen af "an ironic political myth faithful 
to feminism, socialism, and materialism," er beslægtet med Gibsons univers. Hendes myte er trofast mere som blasfemi, der jo implicit handler om at tage noget meget alvorligt, end som identifikation og andagtsfuld respekt (Haraway,1991:149). Molly, den kvindelige hovedperson i Neuromancer, inkarnerer i science fiction form mange af de træk, som Haraway vil have os til at tænke over i det virkelige og vel at mærke nutidige liv. Hendes indstilling adskiller sig hermed fra systemudviklernes ekspropriering af cyber-begrebet, idet hun søger at etablere et andet rum og mødested for tolkning af teknovidenskaberne og deres sociale og samfundsmæssige betydning. Hvor Gibson bruger science til at skabe fiktion, bruger Haraway myten til at anskueliggøre, hvordan moderne teknovidenskaber beror på visioner og dermed fiktioner om, hvad det vil sige at være menneske og hvad natur er. Fiktioner, hvis betydning ikke kan rummes inden for hverken dominerende natur- eller kulturvidenskabelige diskurser.

Pointen er, at 'klassiske' moderne og humanistiske positioner, der stiller samfund og moderne teknik i opposition til hinanden, og bringer orden i verden ved hjxlp af dualismer, ikke formår at opfange, hvordan disse områder relaterer sig til hinanden. Vi mangler simpelthen et sprog eller et dækkende 'kort' af den verden, vi frembringer, og ikke mindst af, hvordan vores egne handlinger og forståelser spiller ind på naturen og vores samspil med den. Vi mangler tilsvarende en forståelse af, hvordan diskurser om køn farver vores forståelser af, hvad der tæller som teknisk og hvad vi opfatter som socialt. Cyborg er en metafor for en diskurs, som udforsker disse relationer, idet cyborgs selv er "wary of holism, but needy for connection." Det vil sige, at de er nysgerrige efter relationer og sammenhænge, men i form af forskelle og forskelssætten og ikke $\mathrm{i}$ form af at reducere alle elementer i helheden til det samme.
"I am making an argument for the the cyborg as a fiction mapping our social and bodily reality and as an imaginative resource suggesting some very fruitful couplings. Michel Foucault's biopolitics is a flaccid premonition of cyborg politics, a very open field.

By the late twentieth century, our time, a mythic time, we are all chimeras, theorized and fabricated hybrids of machine and organism; in short we are cyborgs. The cyborg is our ontology; it gives us our politics. The cyborg is a condensed image of both imagination and material reality, the two joint centres structuring any possibility of historical transformation. (...) This chapter is an argument for pleasure in the confusion of boundaries and for responsibility in their construction." (Haraway, 1991: 150)

Overfor feminister, der i debatten i 70'erne og 80'erne afviste den moderne videnskab som kvindefjendsk, peger Haraway på, at den er så stor en del af vores egen virkelighed og af os selv, at vi i stedet bør undersøge den og påtage os et ansvar for, hvordan den virker og er infiltreret i vores eksistens. Hun gør det ydermere på en særdeles elegant måde, hvor hun viser, at der ikke er den radikale forskel på den moderne verden og videnskab i forhold til den førmoderne, som dem der tager afstand fra moderne videnskab postulerer. Sagt med andre ord, så hævder hun, at den moderne verden ikke er 'affortryllet.' Max Weber tog fejl med sin tese om det moderne samfunds 'Entzäuberung.' Det er vores forståelse af den videnskabelige praksis og dens rationalitet, som har været for indskrænket. Fortryllelse peger heller ikke nødvendigvis på en harmonisk sameksistens med naturen. Fortryllelse er risky business, nu som før. Haraways manifest tilbyder en række billeder på, hvordan man kan gebærde sig i et sådant farvand. Hun argumenterer for, at videnskaben og især de nye bio- og informationsteknologier er med til at restrukturere 
vores verden på måder, der arbejder i det relationelle plan, hvorfor det også må være udgangspunktet for afsøgninger af mulige feministiske positioneringer.

"Technologies and scientific disourse can be partially understood as formalizations, i.e. frozen moments, of the fluid social interactions constituting them, but they should also be viewed as instruments enforcing meanings. The boundary is permeable between tool and myth, instrument and concept, historical systems of social relations and historical anatomies of possible bodies, including objects of knowledge. Indeed, tool and myth mutually constitute each other." (1991: 164)

Identiteter som køn, race eller klasse må betragtes som grundlæggende historiske og ikke essentialistiske kategorier, modsætningsfyldte, sammensatte og strategiske. Kvinde er "a highly complex category, constructed in contested scientific discourses and other social practices."

Cyborgmetaforen er efter min opfattelse en raffineret strategi, der peger på forståelser og handlemuligheder, der er akkurat lige så relevante i dag som i 1984. Men som med alle andre metaforer afhænger dens virkning i høj grad af, om det 'system af almindeligheder,' som den etablerer, om hele det konnotative felt, der knytter sig til den, er attraktivt og til at afkode på en meningsfuld måde for læseren. Skal man forstå de mange lag af mening, den rigdom af konnotationer, der er indeholdt i kondenseringen, kræver det uden tvivl et vist kendskab til brugen af cyberbegrebet og kybernetikken både $\mathrm{i}$ informations-videnskaben og $\mathrm{i}$ science-fiction. Det er ikke teknik og åndløs materie, der kobles, som en (ubevidst) kartesisk læsning kunne tolke det, hvor en skelnen mellem res cogitans og res extensa fungerer som filter. Det er tværtimod et billede, der blandt andet i kraft af cyberbegrebet opløser dualismer og samtidig angiver en gensidig konstituering af på den ene side videnskab, især informationsvidenskaberne, inklusive den moderne biologi, og på den anden side en levende natur, som et ansvarligt og kraftfuldt udtryk for den historiske virkelighed, vi lever i i dag.

Haraways metaforiske tilgang opfatter jeg som en kritisk strategi, der ikke ser det som sin hovedopgave at diskutere, hvilken teori, der er mest korrekt, men i stedet er optaget af at forstå, hvordan forskellige synsmåder, metaforer, virker $\mathrm{i}$ verden og spiller sammen med magtstrukturer i øvigt. Ingen teori kan efter denne opfattelse på forhånd afgøre, hvilke virkninger, der er forbundet med at implementere den i verden. Det er et spørgsmål om ansvarlighed inden for den videnskabelige verden, men også alle andre rum, som viden konstitueres $\mathrm{i}$, et spørgsmål om at være ydmyg (modest). Ingen kan vide på forhånd, hvordan det, der udtænkes i laboratorier, og dermed en afgrænset verden, vil virke, når det implementeres uden for laboratoriet. Videnskab kan ikke afgrænses til alene at betegne det, de formelle videnskabelige 'kasketter' foretager sig eller beskriver, men må ses i forhold til hele det netværk, der aktualiseres omkring den. Cyborg er således en metafor, der på én gang rummer Gibsons dystopiske og melankolske univers og designerens længselsfulde og optimiske handlingsenergi og tolker dem ud fra ambitionen om en ikke naiv ansvarlighed.

Med de omfattende politiske og ikke blot markedsmæssige satsninger på udvikling af informationsteknologi, som finder sted på internationalt plan i disse år, blander de metaforiske universer, jeg har skitseret, sig mere og mere i vores dagligdag. Cyborgens indsigter og strategier bliver påtrængende $\mathrm{i}$ afkodningen af informationsteknologiske strategier, for eksempel i forhold til debatten og politikken i Danmark. Med en 'fornemmelse for cyborg' går turen nu til 'bygge-pladsen' for det, der kaldes informationssamfundet i Danmark. 


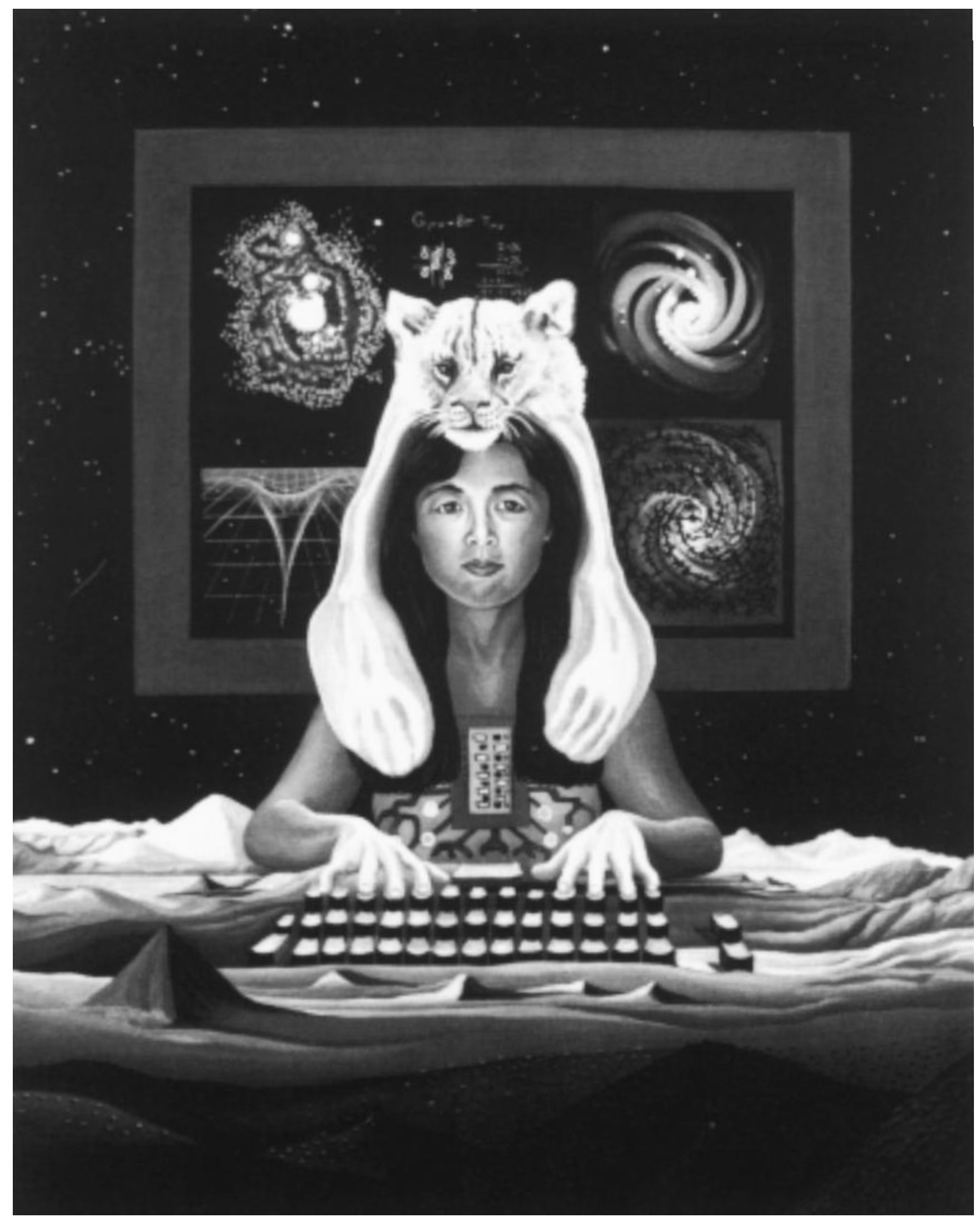

Lynn Randolf, Cyborg, 1989, olie pà lerred 


\section{INFOSAMFUNDSRAPPORTEN I CYBORG PERSPEKTIV}

I 1994 udkom Info-Samfundet År 2000, et forslag til en dansk politisk strategi for informationssamfundet (Dybkjær \& Christensen, 1994). Den danske regering fulgte hermed i kølvandet på andre initiativer, ikke mindst den amerikanske Al Gores "The Information Super Highway" og Bangemann rapporten i europæisk sammenhæng. Rapporten markerer et skift både i politisk stil og strategi. Der er ikke tale om en betænkning i den sædvanlige saglige genre, men om et projektoplæg, som på visionær vis skulle tegne et billede af de muligheder, et kommende informationssamfund giver danskerne, samt formulere en informationspolitik. Den henvender sig ikke blot til politikere, men søger at nå den brede offentlighed. Den er formulereret i en stil, hvor fakta og fiktion blandes med store forventninger til, hvad IT kan gøre for danskerne. En usædvanlig cocktail, sammenlignet med den økonomiske nyttediskurs, der ellers har præget området på det politiske plan.

Rapporten er bygget op som en række konkrete forslag til politikker inden for stort set alle samfundsmæssige områder, hvor det offentlige har noget at skulle have sagt. Vægten ligger på hvordan IT kan lette og især 'understøtte' arbejde og kommunikation, samfundets og virksomhedernes økonomi, borgernes personlige udvikling, demokratiet og tillige de handicappedes situation.

Info-Samfundet år 2000 indskriver sig således $i$ en udpræget moderne, fremskridtsoptimistisk diskurs. Teknologi har, som Andreas Huyssen bemærker, altid været modernitetens motor og modernitetens tankefigurer aktualiseres automatisk $\mathrm{i}$ et sådant teknologiprojekt, ofte fulgt af et historisk hukommelsestab (Huyssen, 1995). Den nye metafor IT, hvor computerteknologi knyttes sammen med andre medier, ikke mindst fjernsyn og telesektoren, gør sit arbejde ved på den ene side at fremhæve, at noget radikalt nyt og ganske ukendt, en informationsteknologisk infrastruktur, venter på at blive udviklet, og på den anden side ved at aktualisere modernitetens 'systemer af almindeligheder' omkring teknologi, hvor teknologien tilskrives den afgørende betydning for samfundets økonomiske og demokratiske udvikling: En optimistisk teknologideterminisme, som kulminerer med forestillingen om, at her har utopia endelig fået en holdeplads (Nørretrandes, 1997). ${ }^{2}$

Rapporten kan siges at markere et skift fra en overvejende teknokratisk opfattelse af computerteknologi til en eksplicit politisering af feltet. ${ }^{3}$ I løbet af 70'erne og 80'erne stødte den teknokratiske opfattelse, som prægede udviklingen af edb i forbindelse med udbygningen af velfærdsstaten, og som baserede sig på en systemteoretisk, kybernetisk forstålse af teknologien (Heide, 1996: 206), på modstand i offentligheden. Feltet blev politiseret for eksempel i form af diskussionen omkring registerproblematikken og frygten for overvågningssamfundet, Orwells 1984 stod klart i den offentlige bevidsthed. Dele af fagbevægelsen så den nye teknologi som et politisk angreb på arbejdernes kvalifikationer og magtpositioner: At betjene teknologi ved hjxlp af et tastatur blev ofte opfattet som et angreb på den mandlige arbejderidentitet, en 'kvindagtiggørelse' (Cockburn,1983). Kritiske forskere og fagbevægelsen hævdede, at teknologien ikke var neutral, og at der var alternativer til de systemteoretiske automatiseringsmetaforer og samarbejdede omkring alternativ teknologiforståelse (Foged et al., 1987). Vi fik teknologiaftaler på arbejdsmarkedet; kvindeforskere advarede mod distancearbejde; og kvindelige dataloger fremdrog, at kvinder har en lang tradition for at håndtere formalismer og programmer, tænk blot på at følge en strikkeopskrift.

Infosamfundsrapporten fra 1994 forholder sig paradoksalt nok overhovedet ikke til disse historiske erfaringer, samtidig med, at 
den benytter sig af begreber, der er udviklet i denne tradition, ikke mindst forestillingen om, at teknologien skal 'understøtte,' ikke automatisere. ${ }^{4}$ Det nye er ikke alene et spørgsmål om teknologien, som forfatterne opfatter det. Politikken er også ny og knytter an til den internationale markedsorientering. Rapportens genre og retorik kan ses som udtryk for, at det også drejer sig om at sælge visionen til privatpersoner og fă dem til at investere i IT i hjemmet. Den kritiske diskurs i 70'erne og 80'erne hævdede, at man skulle stille krav til teknologien, og arbejdede med indflydelse ud fra deltagerdemokratiske ideer. Denne diskurs eksproprieres nu af en diskurs, som konstruerer den personlige bruger af IT. Ikke som kritisk forbruger, men som et selvudviklingsprojekt, IT kan 'understøtte,' og som har entreprenøren som ideal: Hver bliver sin egen virksomhed, hvor økonomi og personlighed går op i en højere enhed takket være IT (duGay \& Salaman, 1992).

De billeder på beherskelse, som fremmanes i forbindelse med internettet og dets potentielle brugere, har desuden rod i populære forestillinger om det teknisk-videnskabelige miljø, som nettet er udviklet i og det ikon for intelligens, det udgør. De erfaringer, som langt de fleste allerede har med teknologien, usynliggøres, og kvinder bliver automatisk $\mathrm{i}$ debatten lig med det andet, B-holdet, det, der ikke kan rummes i den rene kategori $A$, men som defineres alene ud fra det. Det er tankevækkende, at selv i et land, hvor kvinder udgør en integreret del af arbejdsstyrken, og hvor kønsroller længe har været under transformation, aktualiseres en diskurs om teknologi og køn. Det indikerer, hvor sammenfiltret forestillinger om køn og teknik er i vores kultur og måske i enhver kultur, idet begge forhold udtrykker elementære menneskelige eksistensvilkår. Men det viser også, hvor ubevidste vi er om dette, og hvilke snævre billeder, vi tillader os at have om at bruge og interagere med teknologi.

Det er ikke min mening at tillægge Info- samfundsrapporten et bevidst kvindefjendsk sigte, og den kan da også læses med blidere eller endda mere kritiske øjne. Pointen er, at den diskurs, den fremskridtsretorik, det system af almindeligheder, der er på spil i tankegangen, implicerer en dualistisk tænkemåde, som alt for let ser kvinder som problemet. Skyggesiderne af den heroiske retorik omkring teknologien projiceres så at sige over på kvinder. Set med cyborg som filter ligger der derfor en opgave i at afkode, hvordan 'tool and myth mutually constitute each other,' (Haraway, 1991: 164) ikke alene $\mathrm{i}$ informationssystemerne, men $\mathrm{i}$ vores mere omfattende forståelse af, hvad vi bruger dem og anden teknologi til konkret og symbolsk. En 'fornemmelse for cyborg' bliver således ikke hængende $\mathrm{i}$ 'the frozen moments' i formalismer og i rapporter og i avisdebatterne og i den betydning, de fremmaner med deres retorik. Den retter også opmærksomheden mod 'the fluid social interactions constituting them.' Politiske tiltag, som de fremstår i medieoffentligheden er blot et af de diskursive rum, et af de laboratorier, teknologien formes i, men også et led i et større netværk.

Retter vi opmærksomheden mod andre mødesteder, viser de modsætninger, som retorikken indeholder, sig hurtigt at kunne blive en klods om benet. For hvad vil det egentlig sige at beherske teknologien, når vi har at gøre med et så ekstremt dynamisk fænomen i en dynamisk verden? Vi har at gøre med en industri, som konstitueres af konstante processer, hvor destabiliseringer af 'frozen moments' veksler med momentvise stabiliseringer, og hvor kategorier som brugere og udviklere ikke længere er fasttømrede positioner. Teknologiudvikling er ikke énmandsværk, men kræver samarbejde på kryds og tværs af veletablerede grænser og involverer foranderlige kompetencer, både i udviklingen af det, vi blackboxer som teknisk, og i arbejdet med at afsøge markedet og opfinde nye anvendelsesmuligheder og behov. IT-industrien er ved at opdage, at kvinder er en stor potentiel del af et mas- 
semarked, som det er værd at tage med, Nogle forestiller sig efterhånden, at kvindelige medarbejdere må kunne bruges til at udvikle IT på måder, der i større udstrækning tiltaler et kvindeligt publikum. Konstruktioner af kvindelige IT og cyberspace identiteter kan muligvis blive et rentabelt felt.

Der er andre rum, laboratorier og mødesteder i de netværk, som konstituerer IT, jo ikke mindst arbejdspladser, hvor IT også formes i de lokale steders sociale og magtmæssige dynamikker, og hvor metaforer for køn, magt og teknik lige så fuldt interagerer. Vi konstruerer og afkoder menneskelige færdigheder ikke mindst $i$ et samspil af denne type metaforer. Vi er kun et lille stykke vej med at forstå omfanget og karakteren af, hvordan metaforer for tid, for køn og for magt former de dominerende teknologiforståelser.

\section{Tilbage TIL NUTIDEN}

I afsøgningerne af de netværk, som køn i cyberspace spindes i, vil jeg slutte med et af de forhold, som undrer mig mest, nemlig patenteringen af fremtiden. Hvorfor hedder et TV program om IT Fremtidsmagasinet? Hvorfor udnævnes teknologi til at repræsentere utopia? Patenteringen af fremtiden producerer dualismer, A- og B-holds tænkning og en tidsforståelse, hvor fremskridtet har en høj pris i form af det, Andreas Huyssen kalder hukommelsestab. En cyborg tilgang anslår større ydmyghed og udforskning af andre måder at tilegne sig noget nyt end den konstante fokusering på fremtiden på bekostning af fortiden og nutiden.

Et episode fra min egen barndom faldt mig ind. Julen 1953 fik min søster og jeg nye dukker i julegave, og vi troner med smil og hver en stor celluloidbabydukke på skødet på det fotografi, min far tog. De var nye og $i$ et nyt materiale, som gjorde dem moderne på den måde, man begyndte at fornem- me i 50'erne. De tidligere yndlingsdukker var i stof, slidte og virkede nu lidt kedelige. Men i sammenligningen gik det op for os, at de havde andre kvaliteter end de nye, kvaliteter, som nu blev tydelige. De fik navnet gammelny dukkerne, og de eksisterer såmænd stadigvæk. Andre fornemmelser for tid end fremtidskolonialiseringen kan måske også aftvinge arbejdet omkring IT andre og flere kvaliteter. For eksempel at vi tillader os en større og rigere indsigt $i$, hvor dyrebar den på alle måder er.

\section{Noter}

1. Nina Lykke har skrevet en glimrende introduktion til Donna Haraway i Kvinder, Køn \& Forskning, (1996) På norsk foreligger en introduktion af Asdal, Kristin et al. (1995). Der findes også en række arbejdspapirer, udgivet af Center for kvindeog kønsstudier i Odense i forbindelse med netværket Køn, Natur, Kultur, som introducerer til feltet i Nina Lykke og Rosi Braidotti 1996. Sidste nummer af Philosophia, Verden om tænkningen, mennesker, ting og natur, er specielt en introduktion til den såkaldte aktør-netværksteori.

2. Hans Siggaard Jensen og Ole Skovsmose giver en redegørelse for teknologideterminisme i bogen Teknologikritik. Nørretranders strategi adskiller sig radikalt fra cyborg tankegangen, idet den har svært ved at rumme forestillinger om heterogenitet.

3 . Jeg kan ikke komme ind på de konkrete politiske tiltag i denne sammenhæng.

4. Dette peger også på begrænsninger i den form for kritisk diskurs, set ud fra en feministisk synsvinkel. En sådan analyse findes i Markussen 1996.

\section{LITTERATURLISTE}

- Asdal, Kristin; Brenna, Brita; Moser, Ingunn \& Refseth, Nina (red) (1995): En kyborg til forandring - Nye politikker i moderne videnskaber og teknologier. TMV Skriftserie Nr.12. Senter for teknologi og menneskelige værdier. Universitetet i Oslo. - Benedikt, Michael (red) (1991): Cyberspace: First Steps. USA. The MIT Press.

Black, Max (1955) Metaphor. in Johnson, M. (red) (1981): Philosophical Perspectives on Metaphor. University of Minnesota Press. 
- Bowker, Geoffrey \& Star, Susan Leigh (1996): Hvordan ting virker. In: Philosophia, tidsskrift for filosofi, årg. 25, 3-4.

- Cockburn, Cynthia (1983): Brothers. Male Dominance and Technological Change. Suffolk:Pluto Press.

- du Gay, Paul \& Salaman, Graeme (1992): The Cult(ure) of the Customer. In: Journal of Management Studies, 29:5.

- Dybkjær, Lone \& Christensen, Søren (red) (1994: Info-samfundet år 2000. Rapport fra udvalget om Informationssamfundet år 2000. Forskningsministeriet.

- Edwards, Paul (1996): The Closed World. Computers and the Politics of Discourse in Cold War America. USA: The MIT Press.

- Foged, Jane, Jørgensen, Troels, Kjær, Arne, Markussen Randi (1987): Håndbog om klubarbejde, edb-projekter og nye arbejdsformer. Århus: HK-forbundet.

- Fox Keller, Evelyn (1985: Reflections on Gender and Science. USA: Yale University Press.

Foucault, Michel (1977: Overvågning og straf.

København: Rhodos.

- Gibson, William (1992): Neuromantiker. Oversat af Arne Herløv Petersen efter Neuromancer, 1984. Viborg. Forlaget Per Kofod.

- Gibson, William (1991): Academy Leader. In Benedict, Michael (ed): Cyberspace: First Steps. USA.

The MIT Press.

- Haraway; Donna (1991): Simians, Cyborgs and Women. The Reinvention of Nature. New York: Routledge.

- Heide, Lars (1996): Hulkort og edb i Danmark 1911-1970. Gylling: Systime.

- Hirschhorn, Larry (1984): Beyond Mechanization. USA: The MIT Press.

- Huyssen, Andeas (1995: Twilight Memories. Marking Time in a Culture of Amnesia. USA: Routledge.

- Lykke, Nina (1996): Kyborg eller gudinde? Feministiske dilemmaer i det sene 20.århundredes øko- og teknokritik. In: Kvinder, Køn \& Forskning. 5.årgang, nr. 4.

- Lykke, Nina \& Braidotti, Rosi (eds.) (1996):

Between Monsters, Goddesses and Cyborgs. Feminist Confrontations with Science, Medicine and Cyperspace. Trowbridge, Wilts: Zed Books.

- Markussen, Randi (1993) : Gender, Culture, and Technology. (Editorial). Sammen med Susanne Bødker redaktør af et tema nummer om Køn, kultur og teknologi af $A I$ \& Society. The Journal of Human-Centred Systems and Machine Intelligence. Vol 7 number 4. Springer Verlag London Limited.
- Markussen, Randi (1996): Politics of Intervention in Design: Feminist Reflections on the Scandinavian Tradition. In: AI \& Society. The Journal of Human-Centred Systems and Machine Intelligence. Springer Verlag London Limited.

- Nørretranders, Tor (1997): Stedet som ikke er. Fremtidens nervar, netvark og internet. Danmark: Aschehoug.

- Olesen, Finn (1992): Metaforer og maskiner. in Philosophia, tidsskrift for filosofi, årg.21 nr. 3-4.

- Olesen, Finn (red). (1996): Verden om tænkningen. Mennesker, ting og natur. Philosophia, tidsskrift for filosofi, årg. 25, 3-4.

- Schutz, Alfred (1975): Hverdagslivets Sociologi. Oversat af Lisbeth Eriksen. København: Hans Reitzel.

- Jensen, Hans Siggaard, Skovsmose, Ole (1986: Teknologikritik. Et teknologifilosofisk essay. Gylling: Systime.

- Suchman, Lucy (1987): Plans and situated actions. The problem of human-computer interaction. Trowbridge, Wiltshire: Cambridge University Press.

- Wiener, Norbert (1963: Menneske og automat. Kybernetikken og samfundet. Oversat af Elsa Gress efter (1950) The Human Use of Human Beings. Cybernetics and Society. Gyldendal. København. - Weber, Max (1971) (1922) Makt og byråkrati. Gjøvik: Gyldendal.

\section{SUMMARY}

The article suggests that questions of sex/gender and advanced information technologies can be addressed through the concept af metaphorical work. By way of this concept it encircles prevaling discourses about sex/gender and technology and analyses the mertaphor af cyberspace within the context of a genealogical approach to the history of information. Furthermore Donna Haraway's cyborg metaphor introduses as an instance of feminist metaphorical work and the article seeks to show that this discourse differs radically from prevailing discourses about technology. Finally it shortly decodes the rhetoric of the Danish information society report enlightened by a 'sense of cyborg'.

Randi Markussen, lektor

Institut for informations- og medievidenskab Århus Universitet 